\title{
PSYCHE
}

Vol. XLIX

SePt.-DeC., 1942

Nos. 3-4

\section{AN ANNECTENT GENUS OF CIMICOIDEA FROM BALTIC AMBER (HEMIPTERA)}

By Robert L. USINGer

University of California, Davis, California

Among the Hemiptera in the Haren collection of Baltic amber insects submitted to me for study by Dr. F. M. Carpenter were five anomalous specimens of the superfamily Cimicoidea. Although bearing a superficial resemblance to certain Miridæ in body form and general facies, closer study disclosed several aberrant characters which suggest relationship with the Microphysid-Anthocorid complex. Actually these specimens do not fit any family as recognized at the present time and hence must assume a place among the annectent Cimicoidea made famous in recent years by Bergroth $(1924,1925)$, McAtee and Malloch (1924, 1926), and China and Myers (1929). Fortunately, some of these specimens are so beautifully preserved that structural details are more readily observed than would be the case with pinned specimens. The points still to be desired would be an unobstructed dorsal and ventral view, a clear view of the veins of the hind wings and a cleared dissection of the male genitalia. All other features show up as clearly as though the specimens had been mounted in Canada balsam.

\section{Electrocoris new genus}

Elongate-oval and moderately robust in body form, suggesting a Bryocorine Mirid at first glance. Head scarcely to moderately deflexed, the upper surface evenly arcuate from base of vertex to apex of clypeus and the gula well developed, as long or longer than buccal opening. Eyes broadly contiguous with pronotum. Ocelli distinct, located laterally on vertex well back 
near posterior corners of eyes. Antennæ inserted laterally immediately in front of eyes, relatively short and stout, the first segment shortest, third twice as long as first, second three times as long as first, and the last segment longest, one-fifth longer than second, the last two segments nearly as thick as basal

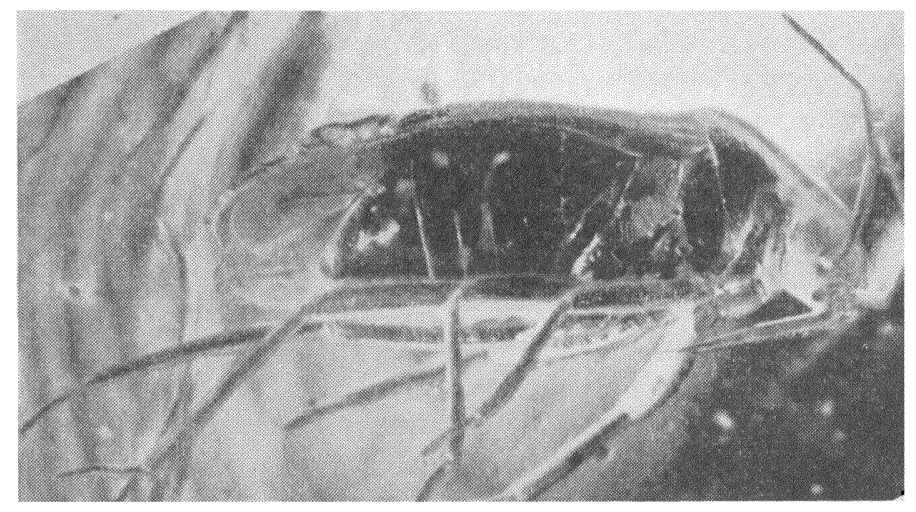

Fig. 1. Electrocoris brunneus Usinger. Allotype, no. 4540, Mus. Comp. Zool.

segments. Rostrum curving downward and backward but not appressed to under surface of head and thorax and not fitting into a rostral groove; slender and reaching between middle and hind coxæ; first segment shortest, membranous, and concealed in all but one specimen where the beak is completely exserted; second segment half as long as third, the third and fourth segments subequal.

Pronotum about one-third longer than head on median line, moderately declivous, the disk distinctly punctate, its sides depressed and lateral margins roundly carinate and feebly sinuate. Posterior margin straight. Scutellum two-thirds as long as pronotum, scarcely elevated except at base, subequilateral, with acute apex.

Hemelytra well developed, the membrane exceeding tip of abdomen by one-sixth the total length of hemelytra; clavus and corium regularly punctate, with short hairs arising in the punctures; commissure of clavus half again as long as scutellum; corium feebly convex and interrupted along middle by a straight emboliar suture reaching three-fourths of distance to apex; 
costal margin moderately arcuate, the edge rounded and uninterrupted, there being no trace of a cuneus or cuneal fracture. Membrane with four distinct, uninterrupted, longitudinal veins, the three inner veins arising from inner half of straight apical margin of corium and running slightly outward or toward the apex of membrane; fourth vein arising at outer fourth of apical margin of corium, curved inward basally and running parallel to other veins apically. Venation of hind wings obscured except in one badly spread specimen. The hamus and decurrent vein are apparently absent though the other veins are perfectly distinct.

Under surface convex, finely punctured and pubescent; ostiolar canals short but distinct, the edges feebly elevated, straight or slightly arcuate and located close to inner posterior margins of metapleura adjacent to hind coxæ. Abdomen with spiracles of segments two to seven clearly visible sublaterally, the posterior margins of segments three to six very straight and complete, that of second segment slightly sinuate but complete, reaching lateral margins. Seventh segment short and concave posteriorly in the male, leaving the strongly sclerotized eighth segment broadly exposed, the eighth segment twice as long as seventh at middle and the ninth segment or genital capsule enormously developed, convex, one-third as long as all the rest of the abdomen. The male capsule is apparently symmetrical and must completely enclose the ædeagus and parameres because only the convex capsule is visible in a perfectly clear side view. In the female the seventh segment is greatly enlarged, being half as long as the rest of the abdomen with its sides rather strongly rounded laterally and then nearly straight until rounded apex. This plate is not cleft and completely conceals the female genitalia.

Legs relatively stout and finely pubescent. Femora feebly incrassate, tibiæ cylindrical. Tarsi more slender, three-segmented, the first segment very short, second and third subequal. Claws slender and apparently without arolia.

Genotype: Electrocoris brunneus n. sp.

Electrocoris is unique in possessing distinct ocelli, an apparently three-segmented rostrum, three-segmented tarsi, four free longitudinal veins in the membrane without cross-veins or cells, a large and apparently symmetrical male genital capsule, 
an entire, unbroken corial margin without trace of cuneus, and a large, uncleft seventh abdominal sternite in the female without trace of an ovipositor. It runs directly to the MicrophysidAnthocorid couplet in China and Myers' key (1929) but does not fit either of these. All of the alternative characters given in this couplet are variable except the one concerning the symmetry of the male genitalia. Electrocoris fits the Microphysidæ in this critical character but agrees with the Anthocoridæ in all of the supplementary characters given.

Pachymerus senius Germar and Berendt (1856) may pertain to Electrocoris as indicated by the introductory paragraph of the original description. "Dies kleine, wenig über eine Linie lange Thierchen, erscheint in der Gestalt des Kopfes, des Halsschildes und der Fühler fast wie ein Capsus, und hat besonders mit Capsus capillaris im Umriss Aehnlichkeit, aber die deutlichen Nebenaugen zeigen, dass es in die Familie der Lygaeoden gehört." It is perfectly true that relationship with the Lygæidæ is indicated, not only by the presence of ocelli, but also by the absence of a cuneus and the presence of four free longitudinal veins in the membrane. However, the Lygæidæ differ fundamentally from the Cimicoidea in general in the possession of abdominal trichobothria and well developed arolia of an entirely different type from the arolia seen occasionally in the Cimicoidea. That Electrocoris has no abdominal trichobothria is indicated by several specimens in which the finest abdominal hairs are clearly visible. Lygæidæ likewise differ from Electrocoris in possessing a distinctly four-segmented, ventrally appressed rostrum, well developed bucculæ, more distinct and differently formed ostiolar canals, and a deeply cleft seventh female sternite which usually accommodates a well developed ovipositor.

There is also a possibility that the much discussed but little understood genus Joppeicus may be related to Electrocoris. Originally described as an Aradid by Puton (1881), Joppeicus paradoxus was later moved to the Lygæid subfamily Oxycareninæ by Bergroth (1898), and thence, as a separate family, Joppeicidæ, back to the Aradoideæ (Reuter, 1910). Mr. China (1933) reëxamined the species and again moved it to the Lygæoidea, this time as a separate family related to the Clerada group of Lygæids. I have never seen Joppeicus but, from a review of the literature including Bergevin (1911), its most 
important characters are: ocelli distinct, rostrum three-segmented, membrane with four free longitudinal veins, ostiolar canals absent, tarsi two-segmented, claws without arolia, spiracles two to seven ventral, seventh abdominal sternite cleft in the female. No mention is made of trichobothria. Obviously, Electrocoris is not to be confused with Joppeicus, but the systematic position of the latter should be studied carefully in any review of hemipterous phylogeny.

\section{Electrocoris brunneus new species}

Figure 1

Male. Body clothed with a rather short pubescence. Head moderately declivous, the gula about as long as buccal opening. Antennæ robust, proportion of segments one to four as $5: 15: 11: 16$. Legs relatively stout. Color of body uniformly light brown. Length $3.12 \mathrm{~mm}$.

Female. Similar to male except for the genitalic differences described above, the slightly longer apical antennal segment (proportion of segments one to four as 5:15:11:18), and the shorter, more robust body form (length $2.51 \mathrm{~mm}$. in the allotype and approximately the same in two partially obscured paratypes).

Holotype (4639), allotype (4640), and one paratype (4641), Museum of Comparative Zoology, Harvard University; and one paratype retained in my collection.

\section{Electrocoris pubescens new species}

Female. Body clothed with a relatively longer, fine, dense pubescence. Head only feebly declivous, the gular region over twice as long as buccal opening. Antennæ relatively slender, the proportion of segments one and two, 4::18, the apical segments broken off. Legs and particularly tarsi slender. Color of hemelytra dark brown, of body beneath, dark brown or nearly black with posterior margins of ventral segments pale. Length $2.5 \mathrm{~mm}$.

Holotype (4642), female, Museum of Comparative Zoology, Harvard University.

Pubescens, though obviously related to brunneus, is strikingly distinct, the longer and denser pubescence, more porrect head, and darker color immediately setting it apart. Both of 
these differ from the possibly congeneric senius Germar and Berendt in which, according to their figure, the scutellum is longer than either the pronotum or the commissure of the clavus and in which the antennal and tarsal segments are differently proportioned.

\section{REFERENCES}

Bergevin, E. de 1912. A propos der Joppeicus paradoxus Put. Bull. Soc. Ent. d'Egypte, 4:80-84, 1 fig.

Bergroth, E. 1898. Sur la place systématique du genre Joppeicus Put. Revue d'Ent., 17:188.

1924. On the Isometopidæ of North America. Notulæ Ent., 4:3-9, 4 figs.

1925. On the "Annectant Bugs" of Messrs. McAtee and Malloch. Bull. Brooklyn Ent. Soc., 20:159-164.

China, W. E. 1933. A new family of Hemiptera-Heteroptera with notes on the phylogeny of the suborder. Ann. Mag. Nat. Hist., (10) 12:180-196, 3 figs., 1 table, 2 plates.

China, W. E. and J. G. Myers. 1929. A reconsideration of the Cimicoid families, with the description of two new spider-web bugs. Ann. Mag. Nat. Hist., (10) $3: 97-125,5$ figs.

Germar, E. F. and G. C. Berendt. 1856. Die im Bernstein befindlichen Hemipteren und Orthopteren der Vorwelt. In Berendt, G. C. Die im Bernstein befindlichen organischen Reste der Vorwelt. Berlin. Band II, Abth. I, p. 30, Tab. III, fig. 14.

McAtee, W. L. and J. R. Malloch. 1924. Some annectant bugs of the superfamily Cimicoideæ. Bull. Brooklyn Ent. Soc., 19:69-82, 20 figs. Errata, loc. cit., p. 127.

1926. Further on annectant bugs. Bull. Brooklyn Ent. Soc., 21:43-47.

Puton, A. 1881. Enumération des Hémiptères recoltés en Syrie par M. Abeille de Perrin avec la description des espèces nouvelles. Mitth. Schweizer ent. Gesell., 6:119-129.

Reuter, O. M. 1910. Neue Beiträge zur Phylogenie und Systematik der Miriden, nebst einleitenden Bemerkungen über die Phylogenie der Heteropteren familien. Acta Soc. Sci. Fennicae, 37, No. 3:1-171, 1 table. 

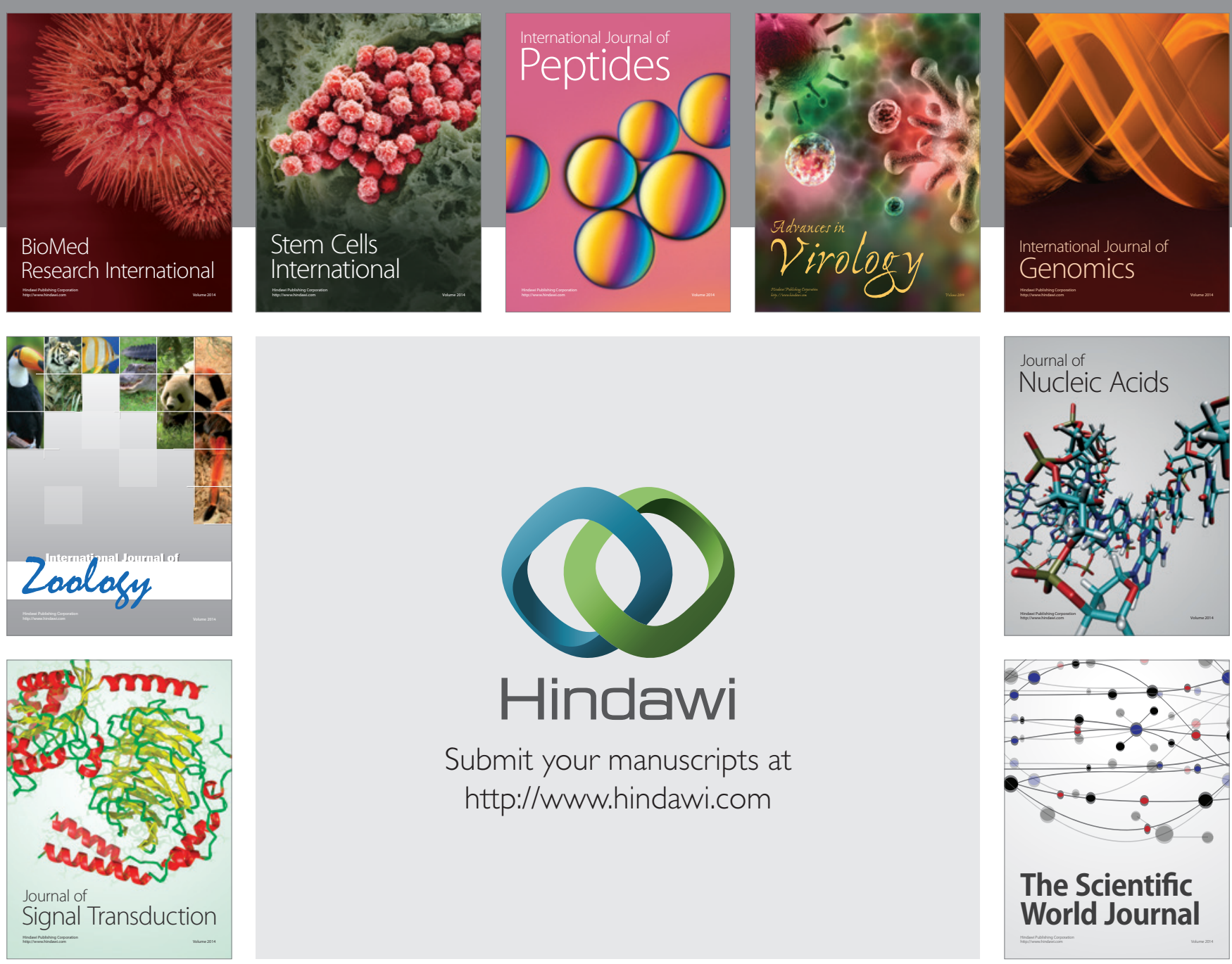

Submit your manuscripts at

http://www.hindawi.com
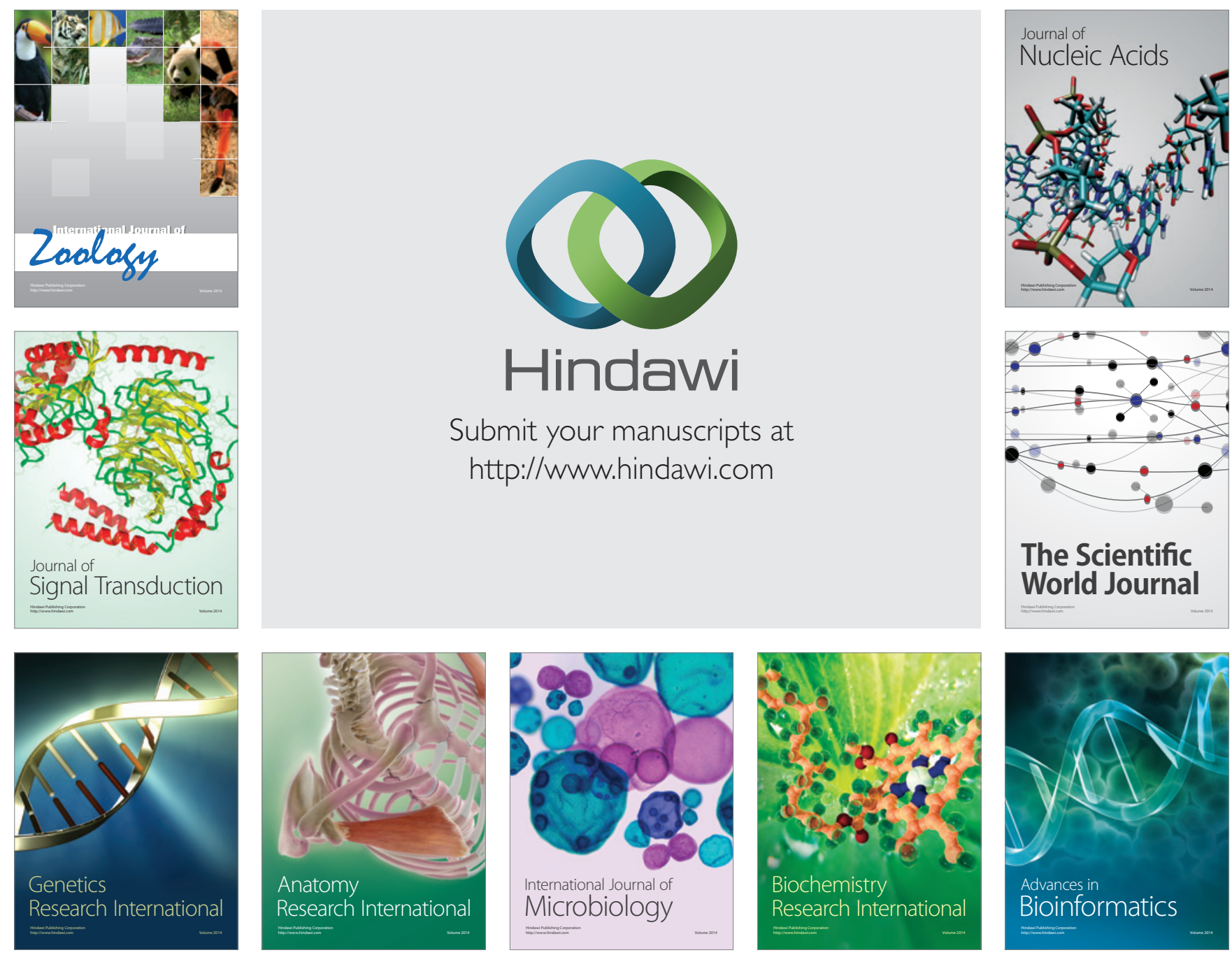

The Scientific World Journal
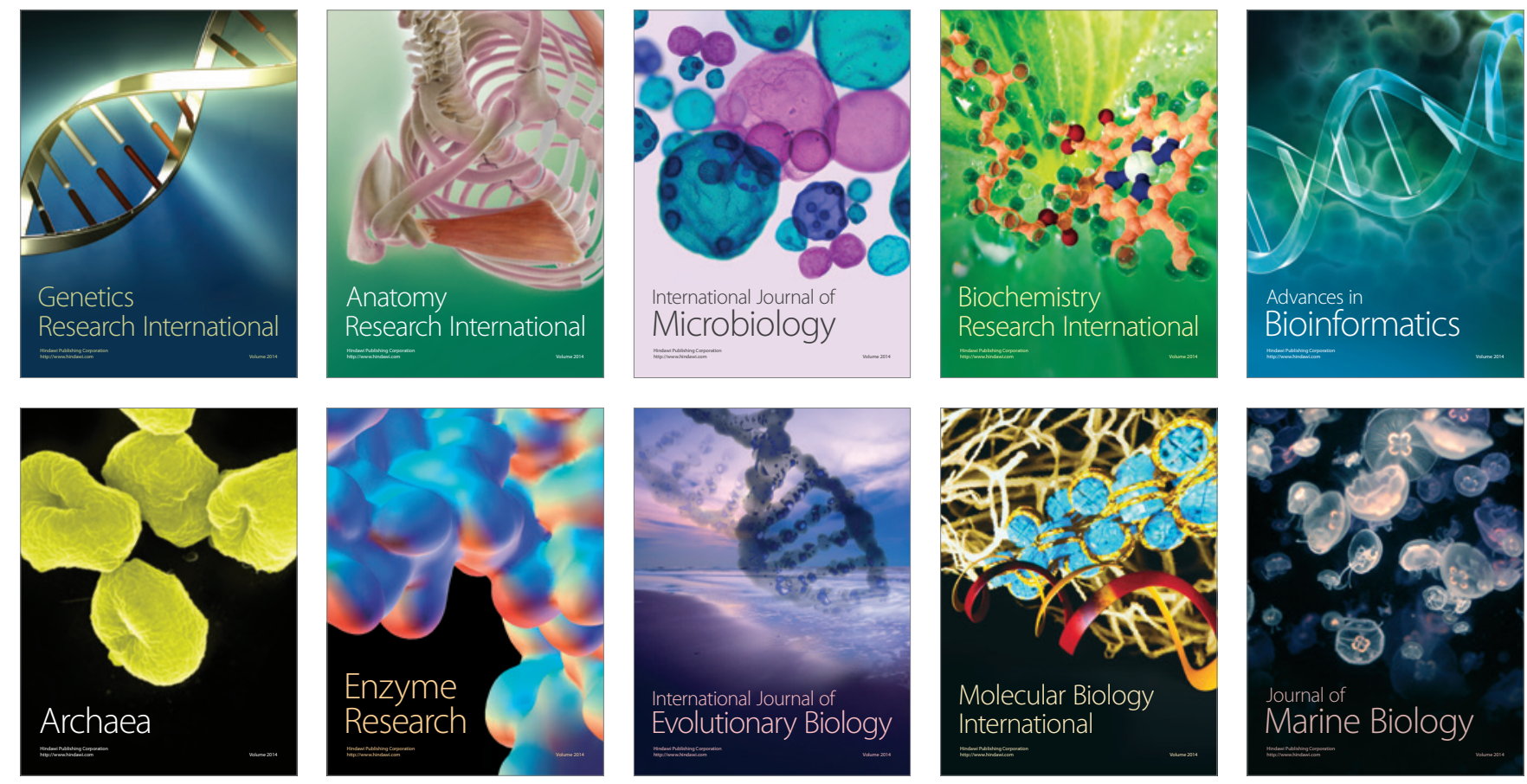